\title{
Phosphate nutrition effects on growth, phosphate transporter transcript levels and physiology of alfalfa cells
}

\author{
S.F. Abu Qamar, T.G. Sors, S.M. Cunningham, B.C. Joern \& J.J. Volenec* \\ Department of Agronomy, Purdue University, 915 West State St., West Lafayette, IN 47907 - \\ 2054 USA \\ (*requests for offprints; Fax:+1-765-496-2926; E-mail: jvolenec@purdue.edu)
}

Key words: amino acids, gene expression, lucerne, Medicago sativa L., phosphate nutrition, phosphate transporter, protein, starch, sugar

\section{Abstract}

Phosphorus deficiency reduces forage yield and stand persistence of alfalfa (Medicago sativa L.).

Our objectives were to isolate and characterize a high-affinity phosphate-transporter $(\mathrm{P}-$ transporter) from alfalfa roots (Medicago sativa L.); determine how phosphorus (P) nutrition impacts P-uptake, growth, and carbohydrate and protein metabolism of alfalfa cells; and learn how expression of the P-transporter is influenced by P nutrition. An 1087-base pair (bp) sequence was isolated using RT-PCR that possessed high nucleotide and amino acid sequence similarity to high-affinity P-transporters. Cultured cells were sampled at 3-day intervals for 9 days while growing in media containing $\mathrm{P}$ concentrations ranging from 0 to $10 \mathrm{mM}$. Media $\mathrm{P}$ concentrations declined rapidly in all $\mathrm{P}$ treatments by day 6 . Low media $\mathrm{P}$ concentrations $(0,0.1$ and $0.5 \mathrm{mM}$ ) reduced cell growth rates compared to higher media P levels $(2.5,5$ and $10 \mathrm{mM})$. Suspension cell cultures supplied 0.5, 2.5, 5, and $10 \mathrm{mM} \mathrm{P}$ had lower starch concentrations by day 3 compared to cells cultured in media containing 0 and $0.1 \mathrm{mM}$ P. Steady-state transcript levels for the high-affinity P- transporter were high in P-deprived cells, but declined within 1 day when cells were provided $10 \mathrm{mM}$ P.

Abbreviations: 2,4-D - 2,4-dichlorophenoxyacetic acid; MS - Murashige and Skoog; P phosphorus; P-transporter - phosphate-transporter 


\section{Introduction}

Alfalfa (Medicago sativa L.) is an important legume used for forage world-wide. Stresses such as low phosphorous (P) availability reduce yield and persistence of this perennial plant (Berg et al., 2005). In response to $\mathrm{P}$ deficiency plants have developed many adaptive mechanisms to increase $\mathrm{P}$ uptake, including synthesis of high-affinity phosphate transporters (P-transporters) in plasma membranes (Bieleski and Lauchli, 1992; Muchhal and Raghothama, 1999; Raghothama, 1999). This transporter is driven by an energy-dependent proton/phosphate symport system, utilizing the proton motive force at the plasma membrane to translocate $\mathrm{P}$ into the roots of plants and cultured cells (Lefebvre et al., 1990; Sakano, 1995). Nine genes for high-affinity P-transporters have been identified in Arabidopsis. Most of the cloned P-transporters are expressed preferentially in roots under P starvation (Karthikeyan et al., 2002). Furthermore, the transcriptional activation of highaffinity P-transporters increased rapidly during P deficiency (Muchhal and Raghothama, 1999). These transporters include: MtPT1 andMtPT2 from Medicago truncatula (Liu et al., 1998a); LePT1 and LePT2 from tomato (Lycopersicon esculentum) (Liu et al., 1998b); AtPT1 and AtPT2 from Arabidopsis thaliana (Muchhal et al., 1996); StPT1 and StPT2 from potato (Solanum tuberosum) (Leggewie et al., 1997); CrPT from Madagascar periwinkle (Catharanthus roseus) (Kai et al., 1997); HVTP1, HVTP2 and HVTP3 from barley (Hordeum vulgare) (Smith et al., 1999); and OsPT11 from rice (Oryza sativa) (Paszkowski et al., 2002). Several studies revealed that these transporters are coded by genes expressed only in roots (Kai et al., 1997; Leggewie et al., 1997; Liu et al., 1998a). In contrast, LePT1, StPT1 and CrPT are expressed in other plant organs including leaves, stems, tubers, and flowers. Using in situ hybridization, Daram et al. (1998) reported that LePT1 mRNA in tomato was localized to rhizodermal cells, including root hairs, root cap cells and neighboring cortical cells. The AtPT1 gene is strongly expressed in epidermal and endodermal layers (Karthikeyan et al., 2002). By comparison, the AtPT2 transcript was present along the entire root length. Newly emerging secondary roots had higher levels of AtPT1 and AtPT2 than did root hairs.

Phosphate nutrition interacts with carbohydrate supply and influences carbohydrate partitioning in plants (Peavey et al., 1977; Rao et al., 1990), including alfalfa (Li et al., 1998). The availability of $\mathrm{P}$ also impacts protein accumulation and utilization in leaves (Rufty et al., 1993) and roots (Li et al., 1998). However, P interacts with soil constituents, especially Fe and Al, 
making it difficult to know the precise $\mathrm{P}$ concentration present in soil solution. Cell suspension culture permits careful control and assessment of $\mathrm{P}$ availability, and how this impacts cell carbohydrate and protein metabolism. Our hypothesis is that P-deficiency will reduce cell growth rates, increase P-transporter expression, and alter the carbohydrate and protein metabolism of cultured alfalfa cells in ways that impact their growth and/or survival. Our objectives were to:

(1) isolate and characterize a high-affinity $\mathrm{P}$ transporter from alfalfa roots;

(2) determine how P nutrition impacts P-uptake, growth, and carbohydrate and protein metabolism of alfalfa cells; and

(3) learn how expression of the P-transporter is influenced by P nutrition.

\section{Materials and methods}

\section{Isolation of alfalfa phosphate transporter (MsPT1) genomic clone}

To isolate the gene encoding the high-affinity P-transporter from alfalfa genomic DNA, a genomic library was built using the Universal Genome-Walker Kit (Clontech, Cat. \# K1807-1). The library was built according to the protocol included in the kit. Alfalfa genomic DNA was isolated from leaves of greenhouse-grown plants (Pioneer Brand '5454') using a protocol described by Dellaporta et al. (1983), digested with restriction enzymes, ligated to adaptors, and used in the PCR amplification procedures according to protocols provided with the kit. The primers used in the PCR amplification were designed to match highly conserved DNA regions of high-affinity P-transporters from 12 different plant species reported in GenBank (www.ncbi.nlm.nih.-gov) (supplementary data on the website).

Amplified fragments were identified by gel electrophoresis in a $0.5 \%$ agarose/TAE gel using $10 \mathrm{mg} \mathrm{ml}^{-1}$ ethidiumbromide. Bands were cut from the gel, and DNA was purified using the Supelco-GenElute Agarose Spin Column Kit (Cat. \#: 5-6500) according to the manufacturer's directions. Fifteen microliters of the purified column extract was incubated for $30 \mathrm{~min}$ at $70^{\circ} \mathrm{C}$ in a solution containing $2 \mu \mathrm{l}$ 10X PCR buffer (containing Mg), $1 \mu \mathrm{l} \mathrm{Taq}$, and $0.4 \mu \mathrm{l}$ ATP in order to add adenines to fragment ends and facilitate cloning. These fragments were ligated into pGEM-T Easy Vector System (Promega; Cat. \# A1380), and cloned in JM 109 competent E. coli 
cells according to the protocols provided. The DNA was sequenced, and the sequence data analyzed using DNAMAN. The alfalfa P-transporter clone was identified based on nucleotide and amino acid sequence similarity to P-transporters from Medicago truncatula (supplementary data on the website).

\section{Plant material and cell culture}

Two experiments, each using suspension cells derived from Pioneer Brand '5454' alfalfa, were conducted to determine how $\mathrm{P}$ availability influences growth, P-transporter transcript abundance, and physiology of cultured alfalfa cells. Seeds were surface-sterilized by immersion in $20 \%$ (v/v) Clorox $\circledast$ for 10 min followed by three washes with sterile water. Seeds were germinated on sterile Whatman \#1 filter paper bridges in $25 \mathrm{ml}$ sterile test tubes containing $5 \mathrm{ml}$ sterile water. Seedlings were grown at $25^{\circ} \mathrm{C}$ under a 16 -h photoperiod of fluorescent light $\left(25 \mu \mathrm{mol} \mathrm{m}^{-2} \mathrm{~s}^{-1}\right)$. The Murashige and skoog (MS) medium was supplemented with $1 \mathrm{mg}^{-1}$ 2,4-dichlorophenoxyacetic acid (2, 4-D) for callus induction. A modified B5g liquid medium supplemented with 1 $\mathrm{mg}^{-1}$ 2,4-D was used for induction of suspension cultures (Gamborg et al., 1968). The B5g was modified by using different molar concentrations of $\mathrm{P}$ : in experiment 1 , cells were transferred to modified B5g containing 0, 0.1, 0.5, 2.5, 5.0, or $10.0 \mathrm{mM} \mathrm{P}$ as $\mathrm{KH}_{2} \mathrm{PO}_{4}$; in experiment 2, cells were grown in B5g containing $0,0.25,5.0$, or $10.0 \mathrm{mM} \mathrm{KH}_{2} \mathrm{PO}_{4}$. In both experiments, $\mathrm{K}_{2} \mathrm{SO}_{4}$ was added in order to maintain constant media $\mathrm{K}$ concentrations.

Explants from 7-day-old seedlings (roots, approximately 5-mm-long) were placed on MS media, sealed with parafilm, and incubated at $27^{\circ} \mathrm{C}$ in the dark. Each Petri dish contained explants from an individual seedling. Eight-week-old primary callus tissue was used to establish suspension cultures in 125-ml Erlenmeyer flasks containing $25 \mathrm{ml} \mathrm{B5g}$ (Gamborg et al., 1968) medium, and agitated at $125 \mathrm{rpm}$ on a gyratory shaker. Cell suspensions were maintained in exponential growth by subculturing $2 \mathrm{ml}$ of settled cell aggregates into $25 \mathrm{ml}$ fresh medium every 9 to 11 days.

\section{Cell harvesting and analysis}

Cells were filtered through a Buchner funnel lined with Whatman \#1 filter paper. Cells were rinsed three times with deionized water, frozen with liquid N2 and lyophilized. The dried samples were weighed, and the dry weight used as an indicator of growth. Dried cell samples 
were ground with a mortar and pestle and stored at $-20^{\circ} \mathrm{C}$ for biochemical analyses. In Experiment 2, a portion of the washed cells was immediately frozen in liquid $\mathrm{N}_{2}$ for RNA analysis (see details below).

\section{Biochemical analyses}

Sugars were extracted by shaking ground, freeze-dried cells $(30 \mathrm{mg})$ in $1 \mathrm{ml} 800 \mathrm{ml}^{-1}$ ethanol and analyzed using anthrone as previously described (Koehler, 1952; Cunningham and Volenec, 1998) using glucose as a standard. The ethanol-extracted residue was dried at $55^{\circ} \mathrm{C}$, re-suspended in $500 \mu \mathrm{l}$ deionized water, and placed in a boiling water bath for $10 \mathrm{~min}$ to gelatinize the starch. Starch was hydrolyzed enzymatically and glucose analyzed as described previously (Cunningham and Volenec, 1998). All protein analysis procedures were conducted at temperatures between 0 and $4{ }^{\circ} \mathrm{C}$. Soluble proteins were extracted from ground, freeze-dried cells (30 mg) using $1.5 \mathrm{ml} 100 \mathrm{mM}$ imidazole buffer (pH 6.5) containing $10 \mathrm{mM}$ 2-mercaptoethanol as described (Cunningham and Volenec, 1998). The resulting supernatant was analyzed for soluble protein (Bradford, 1976) using bovine serum albumin as a standard. Amino acids were extracted by suspending $30 \mathrm{mg}$ of freeze-dried tissue in $1 \mathrm{ml} 100 \mathrm{mM}$ sodium phosphate buffer (pH 6.8) containing $1 \mathrm{mM}$ phenylmethylsulfonylfluoride and $10 \mathrm{mM}$ 2-mercaptoethanol. Colorimetric analysis of amino acids in the supernatant was performed with ninhydrin (Rosen, 1957) using glycine as a standard.

\section{Tissue $P$ analysis}

Freeze-dried tissues (15-20 mg) were digested in $5 \mathrm{ml} 18 \mathrm{M}$ HNO3 in $50 \mathrm{ml}$ digestion tubes using the procedure of Nelson and Sommers (1973). Volumes were adjusted to $35 \mathrm{ml}$ with double deionized water and samples mixed. Total $\mathrm{P}$ was determined colorimetrically using the methods of Chen et al. (1956).

\section{RNA extraction and northern analysis}

These analyses were conducted using suspension cells from Experiment 2. Total RNA was isolated from $2 \mathrm{~g}$ (fresh weight) of cell suspension tissues ground with mortar and pestle in liquid N2 using hot phenol method (Gana et al., 1998). Total RNA (20 $\mu \mathrm{g})$ was separated on 1.5\% agarose, $6 \%$ (v/v) formaldehyde gels (Lehrach et al., 1977). The RNA was transferred to Zeta- 
156

157

158

159

160

161

162

163

164

165

166

167

168

169

170

171

172

173

174

175

176

177

178

179

180

181

182

183

184

185

186

probe membranes after electrophoresis (BioRad, Richmond, CA). Membranes were prehybridized in $0.12 \mathrm{M} \mathrm{Na} 2 \mathrm{HPO} 4(\mathrm{pH}$ 7.2), 7\% SDS, 50\% (v/v) formamide, $0.25 \mathrm{M} \mathrm{NaCl}, 1 \mathrm{M}$ EDTA for $4 \mathrm{~h}$ at $42^{\circ} \mathrm{C}$ with slow shaking. The insert from the isolated MsPT1 was ${ }^{32} \mathrm{P}$-labeled using the random primer method (Feinberg and Vogelstein, 1983). Hybridization and washing of membranes were done as described by Gana et al. (1998). Membranes were exposed to X-ray film at $) 80^{\circ} \mathrm{C}$.

\section{Statistical analysis}

Both studies were designed as randomized complete-block experiments with three replications. To provide sufficient cell mass for analysis; four flasks in Experiment 1 and six flasks in Experiment 2 were combined to form each replicate-treatment combination. Variation was partitioned into $\mathrm{P}$ treatment, day, and replicate main effects, and the $\mathrm{P} x$ day interaction. Where F-tests were significant $(p \leq 0.05)$, differences among the treatment means were determined by calculating the least significant difference (LSD, $p \leq 0.05$ ) (Snedecor and Cochran, 1980). All statistical analyses were carried out using SAS (SAS Institute, 1999).

\section{Results and discussion}

Identification and characterization of an alfalfa cDNA homologous to high-affinity P-transporter (MsPT1)

The goal of this research was to isolate and characterize a high-affinity P-transporter from alfalfa and use it to determine how P nutrition impacts cell growth and physiology, P-uptake, and Ptransporter transcript levels. A 1087-bp alfalfa clone (MsPT1) was isolated that possessed high nucleotide sequence similarity to high-affinity P-transporters reported for other species including Medicago truncatula (supplementary data on the website). The MsPT1 clone shared 95 and 96\% nucleotide sequence identity with the high-affinity P-transporters MtPT1 and MtPT2, respectively, from M. truncatula. The predicted amino acid sequence for MsPT1 possesses high similarity to MtPT1 (96\%) and MtPT2 (98\%) P-transporters from Medicago truncatula (supplementary data on the website). The sequence for MsPT1 has been deposited in GenBank as Accession AY366351 (http://www.ncbi.nlm.nih.gov/).

Cell growth 
187 Dry weight accumulation was used as an indicator of cell growth. The $\mathrm{P}$ and day main effects

188 and the $\mathrm{P} x$ day interaction were significant in Experiment 1. Averaged over days, the 2.5, 5 and $10 \mathrm{mM} P$ treatments had increased dry weight when compared to the $0,0.1$ and $0.5 \mathrm{mM} \mathrm{P}$ treatments (Figure 1). The interaction was significant because cell dry weights were similar among all treatments on days 0 and 3, but increased significantly by day 6 for cells provided 2.5 $\mathrm{mM}$ or more P. In addition, alfalfa cells provided $10 \mathrm{mM}$ P had greater mass on day 6 when compared to cells provided 2.5 and $5 \mathrm{mM} \mathrm{P}$, but by day 9 cell mass of the 5 and $10 \mathrm{mM} \mathrm{P}$ treatments were similar.

The positive impact of $\mathrm{P}$ on cell growth that we observed in this study with alfalfa has been observed with plants and/or cells of other species including Azolla (Bieleski and Lauchli, 1992), opium poppy (Papaver somniferum) (Curtis et al., 1991), and tomato (Lycopersicon esculentum) (Biddinger et al., 1998). Growth of alfalfa cells was greatest when provided $10 \mathrm{mM}$ P. In other species, a minimum cellular P concentration below which cells are P-limited has been reported. Cell growth rates in culture can be limited by $\mathrm{P}$ when provided at the 'standard' media concentration of 1.25 mM (Curtis et al., 1991; Elliot et al., 1993; Murashige and Skoog, 1962). Critical P concentrations of 40 to $90 \mu \mathrm{mol} \mathrm{g}^{-1}$ cells have been reported for Papaver somniferum (Curtis et al., 1991), Daucus carota (Dougall and Weyrauch, 1980), and Acer pseudoplatanus (Rebielle et al., 1982).

\section{Sugar and starch concentrations}

We assayed media sugar concentrations to determine if media sugar limited cell growth at high media $\mathrm{P}$ concentrations. The $\mathrm{P}$ and day main effects and $\mathrm{P}$ - day interaction were significant for media sugar concentration (Figure $2 \mathrm{a}$ ). On days 0 and 3 after transfer there was no impact of $\mathrm{P}$ treatment on media sugar concentration. On day 6 media sugar concentrations declined significantly in the 2.5 to $10 \mathrm{mM} P$ treatments, and by Day 9 , the 5 and $10 \mathrm{mM}$ P treatments were essentially devoid of media sugar, while a significant decrease in media sugar concentration was evident in the other P treatments.

The $\mathrm{P}$ and day main effects and $\mathrm{P} \mathrm{x}$ day interaction also were significant for cell sugar concentration. Sugar concentration of cells was initially $12 \mathrm{lg} \mathrm{mg}$ ) 1 or greater on day 0 , and for reasons that are not clear, lower in cells provided $0.5 \mathrm{mM} \mathrm{P}$. Cell sugar concentrations declined markedly by day 3 irrespective of media P concentration (Figure 2). Sugar concentrations of 
218 cells provided $0,0.1$, and $0.5 \mathrm{mM}$ P were significantly lower than the other P treatments on day 6

219 despite having high media sugar concentrations (Figure 2). On day 9 cell sugar concentrations of the 0.5 and $2.5 \mathrm{mM}$ P treatments were higher than the other P treatments. The low sugar concentration of cells growing in 5 and $10 \mathrm{mM} \mathrm{P}$ was associated with sugar depletion of the media by day 9 , whereas the low cell sugar concentrations observed in the 0 and $0.5 \mathrm{mM} \mathrm{P}$ treatments resulted from reduced sugar uptake from a sugar-rich media by these P-deprived cells. Adequate media $\mathrm{P}$ was essential for rapid uptake and metabolism of sugar from the media and use of intracellular starch pools.

Although there are no published reports describing the impact of media $\mathrm{P}$ concentration on media sugar concentrations, previous research has shown a relationship between $\mathrm{P}$ availability and carbohydrate accumulation in plant organs. Fredeen et al. (1989) found that soybean roots supplied $200 \mu \mathrm{M}$ P contained lower sucrose concentrations than did roots of plants supplied $10 \mu \mathrm{M}$ P. The net $\mathrm{CO}_{2}$ assimilation of plants also is influenced by $\mathrm{P}$ availability, and this may indirectly impact tissue sugar concentrations. Biddinger et al. (1998) found that plants provided $250 \mu \mathrm{M} P$ had a $\mathrm{CO}_{2}$ assimilation rate that was nearly 2.5 times greater than that of plants receiving $01 \mathrm{M} \mathrm{P}$.

The $\mathrm{P}$ and day main effects and $\mathrm{P} \mathrm{x}$ day interaction for cell starch concentration were significant. Cell starch concentrations were high on Day 0 irrespective of media P concentration (Figure 2). Thereafter, increasing media $\mathrm{P}$ concentration generally decreased cell starch concentrations. Suspension cell cultures supplied 0.5, 2.5, 5.0, and 10.0 mM P had lower starch concentrations on day 3 when compared to cells cultured in media containing 0 and $0.1 \mathrm{mM} \mathrm{P}$. Although starch concentrations did not decline on day 6 in cells provided 2.5 to $10 \mathrm{mM} \mathrm{P}$, starch concentrations were lower on day 6 in cells cultured in media containing 0.1 and $0.5 \mathrm{mM} \mathrm{P}$. By day 9, starch concentrations of cells provided 0,5 , and $10 \mathrm{mM} \mathrm{P}$ declined over day 6 starch concentrations for these $\mathrm{P}$ treatments. Previous research has shown a close association between tissue starch depletion and tissue P concentrations. Qui and Israel (1992) reported that starch concentrations in leaves of P-deficient soybean (Glycine max) were consistently higher than those of plants receiving sufficient $P$.

\section{Cell amino acid and protein concentrations}


The $\mathrm{P}$ and day main effects and $\mathrm{P} \mathrm{x}$ day interaction were significant for cell amino acid concentrations (Figure 3a). As expected, cell amino acid concentrations were similar on day 0. On day 3, amino acid concentrations were greater in cells grown in media containing 0.1 and 0.5 $\mathrm{mM} \mathrm{P}$ when compared to cells provided 2.5 and $5 \mathrm{mM}$ P. However, at day 6 , there was a significant decrease only in the 0.1 and $0.5 \mathrm{mM}$ P treatments from 0.16 and $0.13 \mathrm{lM} \mathrm{mg}) 1$ to 0.07 and $0.04 \mu \mathrm{M} \mathrm{mg}^{-1}$, respectively. At Day 9, amino acid concentrations were highest in cells provided $0,0.1$ and $0.5 \mathrm{mM} \mathrm{P}$, extremely low in cells provided $10 \mathrm{mM} \mathrm{P}$, with the other $\mathrm{P}$ treatments intermediate.

Phosphorus deficiency has been found to alter amino acid accumulation in plant tissues and cells. In a manner similar to P-starved alfalfa cells on day 9 (Figure 3a), Duff et al. (1989) reported that concentrations of free amino acids increased six fold in P-starved Brassica nigra suspension cells. Ukaji and Ashihara (1986) observed similar results in P-deficient suspension cells of (Catharanthus roseus). Rufty et al. (1993) observed increased amino acid concentrations in roots of P-deficient soybean and tobacco (Nicotiana tabacum L.). With $10 \mathrm{mM} \mathrm{P}$, amino acid concentration of alfalfa cells declined to very low levels on day 9. This coincided with cells entering a stationary phase of growth between days 6 and 9 (Figure 1) and the depletion of media sugar (Figure 2). Additional work is necessary to determine if amino acids were used as an energy source to support cell metabolism in this P-rich but carbon-limited media. The $\mathrm{P}$ and day main effects and $\mathrm{P} \mathrm{x}$ day interaction for cell protein concentration were significant. Cell protein concentrations were generally similar when cells were transferred to media containing the contrasting $\mathrm{P}$ concentrations on day 0 (Figure $3 \mathrm{~b}$ ). Media P concentrations of $2.5 \mathrm{mM}$ or greater resulted in higher protein concentrations on day 3 as compared with day 0 . In addition, protein concentrations increased significantly between days 0 and 3 in cells cultured in media containing $0 \mathrm{mM} \mathrm{P}$. Between days 3 and 6 , protein concentrations of cells cultured in $0.5 \mathrm{mM} P$ nearly doubled, while little change in cell protein concentration over this time interval for the other P treatments. By day 9, protein concentrations of cells cultured in $10 \mathrm{mM} \mathrm{P}$ were significantly lower than cells provided lower media P concentrations. These same cells had extremely low amino acid concentrations (Figure 3a); a situation that could result from use of proteins and amino acids as a carbon source given the very low media sugar concentrations for this treatment (Figure 2a) and the likelihood of high demand for carbon as a source of energy. In 
278

279

280

281

282

283

284

285

286

287

288

289

290

291

292

293

294

295

296

297

298

299

300

301

302

303

304

305

306

307

308

contrast, protein concentration of cells provided $0 \mathrm{mM} \mathrm{P}$ were significantly higher than that of cells grown in P-containing media.

Phosphorus availability can impact protein accumulation in plants and cultured cells. Consistent with our observations of days 3 and 6, Duff et al. (1989) reported that P starvation of Brassica nigra suspension cells decreased soluble protein concentrations 1.5 -fold. By day 9 , protein concentrations of alfalfa cells grown in $10 \mathrm{mM} \mathrm{P}$ had low protein concentrations (Figure 3b) that were positively associated depletion of amino acids from these cells grown in P-rich, but carbonlimited conditions. Taproots of P-deficient alfalfa had reduced protein concentrations, leading Li et al. (1998) to speculate that low $\mathrm{N}_{2}$ fixation could limit $\mathrm{N}$ assimilation and root protein synthesis when $\mathrm{P}$ is limiting.

\section{Media and tissue P concentrations}

The $\mathrm{P}$ and day main effects and $\mathrm{P}$ - day interaction were significant for media $\mathrm{P}$ and cell $\mathrm{P}$ concentrations. On Day 0, there was an expected significant difference in media $\mathrm{P}$ concentration that was due to the P treatments that were imposed on that day (Figure 4a). By Day 3, P concentration of media in flasks initially provided $2.5,5$ and $10 \mathrm{mM} \mathrm{P}$ declined significantly to 0.4, 1.6, 5.5 mM P, respectively. Media P concentration declined to near $0 \mathrm{mM}$ in all $\mathrm{P}$ treatments by day 6 . Surprisingly, media P concentration increased in $0,0.1$ and $0.5 \mathrm{mM} \mathrm{P}$ treatments at day 9, apparently as cells in these treatments excreted P. Media P concentration of cells grown in $10 \mathrm{mM} P$ continued to decline between days 6 and 9 .

No significant difference in cell $\mathrm{P}$ concentration was observed on day 0 (Figure $4 \mathrm{~b}$ ). This would be expected since cells were sampled immediately after transfer to their respective $\mathrm{P}$ treatments and did not have sufficient time to acquire $\mathrm{P}$ from the media. Cell $\mathrm{P}$ concentrations did not differ significantly among P treatments on day 3 , but cells growing in media containing $10 \mathrm{mM} \mathrm{P}$ had higher $\mathrm{P}$ concentrations on days 6 and 9 when compared to cells grown in media containing 0.5 $\mathrm{mM} \mathrm{P}$ or less. The minor changes in cell $\mathrm{P}$ concentration would be expected if increases in media P stimulated cell growth, which, in turn, would dilute cell P concentrations. In both shoots and roots of aeroponically grown tomato, $\mathrm{P}$ concentration increased significantly in response to increased media $\mathrm{P}$ in the nutrient solution (Biddinger et al., 1998). However, it is clear from this study that cell (tissue) $\mathrm{P}$ concentration alone does not adequately reflect changes in media $\mathrm{P}$ availability or P uptake rate and flux (Figure 4). 
To understand the impact of media $\mathrm{P}$ on $\mathrm{P}$ uptake, we calculated $\mathrm{P}$ acquisition by cells (cell mass $\mathrm{x}$ cell $\mathrm{P}$ concentration) over time (Figure $4 \mathrm{c}$ ). The $\mathrm{P}$ and day main effects and the $\mathrm{P}$. Day interaction were significant for cell $\mathrm{P}$ uptake. On days 0 and 3 there were no significant effects of media $\mathrm{P}$ concentration or cell $\mathrm{P}$ mass. By day 6 , cells growing in media containing $2.5 \mathrm{mM}$ or greater $\mathrm{P}$ concentrations had acquired greater amounts of $\mathrm{P}$ when compared to the other $\mathrm{P}$ treatments; a difference that was also evident on day 9.

To relate changes in media $\mathrm{P}$ concentration to $\mathrm{P}$ acquisition, $\mathrm{P}$ uptake rates were calculated for each treatment and time interval based on changes in cell P contents over time (Figure 5). Over the first interval, days 0 to 3, there were no differences in $\mathrm{P}$ uptake rate. Highest $\mathrm{P}$ uptake rates occurred over the interval from days 3 to 6 as $\mathrm{P}$ uptake rate increased significantly for cells provided 2.5, 5.0, and $10.0 \mathrm{mM} \mathrm{P}$ when compared with the other $\mathrm{P}$ treatments. The $\mathrm{P}$ uptake rate declined by the day 6 to 9 interval for cells provided 5 and $10 \mathrm{mM} \mathrm{P}$ as media $\mathrm{P}$ concentrations began to limit $\mathrm{P}$ uptake of cells in these treatments.

\section{P-Transporter steady-state transcript levels}

The $\mathrm{P}$ uptake potential in alfalfa cells was assayed in Experiment 2 by determining steady-state transcript levels for a high-affinity P-transporter using theMsPT1 clone (supplementary data on the website) as a probe. Northern blot analysis (Figure 6) revealed generally enhanced transcript level for this P-transporter in cells grown in P-deficient media. Cells provided 0 or $0.25 \mathrm{mM} \mathrm{P}$ in the media had high transcript levels throughout the study. There was a significant increase in cell $\mathrm{P}$ uptake rate between days 3 and 6 for cells grown in 5 or $10 \mathrm{mM}$ P media, and steady-state transcript levels for the high-affinity P-transporter declined markedly within 1 day of cell transfer. However, there was no increase in $\mathrm{P}$ uptake in cells grown in media containing low (0 or $0.25 \mathrm{mM}$ P) P concentrations, and, under these conditions, transcript levels for the Ptransporter remained high.

Several experiments have studied the role of high-affinity P-transporters in plant P uptake. Malboobi and Lefebvre (1995) and Leggewie et al. (1997) both reported higher transcript levels for the high-affinity P-transporter under conditions of P deprivation. Muchhal and Raghothama (1999) reported that the expression of the P-transporter, LePT1, in tomato was altered by P availability of the growth medium. Under P deficiency, mRNA of the LePT1 gene accumulated in tomato roots to a much greater degree than in the roots of P-sufficient plants. Both transcripts 
of MtPT1 and MtPT4 genes from Medicago truncatula were abundant in roots provided minus-P nutrient (Burleigh and Harrison, 1998; Chiou et al., 2001). Transfer of plants to P-deficient media induced transcript accumulation within $24 \mathrm{~h}$, confirming what we observed for these alfalfa cells that there is close coordination of P deficiency and steadystate transcript levels for this gene.

\section{Conclusion}

Phosphate-induced changes in transcript abundance for a putative high-affinity P-transporter in cultured alfalfa cells were similar to whole-plant responses reported previously. Rapid and extensive changes in cell $\mathrm{P}$ concentrations resulted from altered media $\mathrm{P}$ levels, and these interacted with cell metabolism resulting in significant changes in cell carbon and nitrogen pools during cell development. Cultured alfalfa cells provide a useful system for studying interactions among P, C, and $\mathrm{N}$ metabolism in this species. Additional studies with soil-grown alfalfa are underway to confirm the impact of $\mathrm{P}$ nutrition on transcript levels for $\mathrm{P}$-transporters, and how $\mathrm{P}$ availability influences $\mathrm{C}$ and $\mathrm{N}$ metabolism at the organ and whole-plant level.

\section{References}

Berg WK, Cunningham SM, Brouder SM, Joern BC, Johnson KD, Santini J \& Volenec JJ (2005) The influence of phosphorus and potassium on alfalfa yield and yield components. Crop Sci. 45: $297-304$

Biddinger EJ, Liu C, Joly RJ \& Raghothama KG (1998) Physiological and molecular responses of aeroponically grown tomato plants to phosphorus deficiency. J. Amer. Soc. Hort. Sci. 23(2): $330-333$

Bieleski RL \& Lauchli A (1992) Phosphate uptake, efflux and deficient in the water fern Azolla. Plant Cell Environ. 15: 665-673

Bradford MM (1976) A rapid and sensitive method for the quantification of microgram quantities of protein utilizing the principle protein dye binding. Anal. Biochem. 2: 248-254

Burleigh SM \& Harrison MJ (1998) Characterization of the Mt4 gene from Medicago truncatula. Gene 216: 47-53

Chen PS, Toribara TY \& Warner H (1956) Microdetermination of phosphorus. Anal. Chem. 28: $1756-1758$ 
371 Chiou T, Liu H \& Harrison MJ (2001) The spatial expression patterns of a phosphate transporter

372 (MtPT1) from Medicago truncatula indicate a role in phosphate transport at the root/soil

373 interface. Plant J. 25: 281-293

374 Cunningham SM \& Volenec JJ (1998) Seasonal carbohydrate and nitrogen metabolism in roots

375 of contrasting alfalfa (Medicago sativa L.) cultivars. J. Plant Physiol. 153: 220-225

376 Curtis WR, Hasegawa PM \& Emery AH (1991) Modeling linear and variable growth in

377 phosphate limited suspension cultures of opium poppy. Biotechnol. Bioeng. 38: 371-379

378 Daram P, Brunner S, Persson BL, Amherein N \& Bucher M (1998) Functional analysis and cell-

379 specific expression of a phosphate transporter from tomato. Planta 206: 225-233

380 Dellaporta J, Wood J \& Hicks JB (1983) A plant DNA mini preparation. Version II. Plant Mol.

381 Biol. Rep. 1: 19-21

382

Dougall DK \& Weyrauch KW (1980) Growth and anthocyanin production by carrot suspension

383 cultures grown under chemostat conditions with phosphate as the limiting nutrient. Biotechnol. Bioeng. 22: 337-357

Duff SMG, Moorhead GBG, Lefebvre DD \& Plaxton WC (1989) Phosphate starvation inducible 'bypasses' of adenylate and phosphate dependent glycolytic enzymes in Brassica nigra suspension cells. Plant Physiol. 90: 1275-1278

Elliot GC, Smith MA \& Bridgen MP (1993) Growth responses of Alstroemeria 'Parigro Pink' to phosphate supply in vitro. Plant Cell Tiss. Org. Cult. 32: 199-204

Feinberg AP \& Vogelstein B (1983) A technique for radiolabeling DNA restriction endonuclease fragments to high specific activity. Anal. Biochem. 132: 6-13

Fredeen AL, Rao IM \& Terry N (1989) Influence of phosphorus nutrition on growth and carbon partitioning in Glycine max. Plant Physiol. 89: 225-230

Gamborg OL, Miller NT \& Ojima K (1968) Nutrient requirements of suspension cultures of soybean root cells. Exp. Cell Res. 50: 151-158

Gana JA, Kalengamaliro NE, Cunningham SM \& Volenec JJ (1998) Expression of beta-amylase from alfalfa taproots. Plant Physiol. 118: 1495-1505

Kai M, Masuda Y, Kikuchi Y, Osaki M \& Tadano T (1997) Isolation and characterization of a cDNA from Catharanthus roseus which is highly homologous with phosphate transporter. Soil Sci. Plant Nutr. 43: 227-235 
Karthikeyan AS, Varadarajan DK, Mukatira UT, D’Urzo MP, Damsz B \& Raghothama KG (2002) Regulated expression of Arabidopsis phosphate transporters. Plant Physiol. 130: 221233

Koehler LH (1952) Differentiation of carbohydrate by anthrone reaction rate and color intensity. Anal. Chem. 24: 1576-1579

Lefebvre DD, Duff SM, Fife CA, Julien-Inalasingh C \& Plaxton WC (1990) Response to phosphate deprivation in Brassica nigra suspension cells. Plant Physiol. 93: 504-511

Leggewie G, Willmitzter L \& Riesmeier JW (1997) Two cDNAs from potato are able to complement a phosphate uptake deficient yeast mutant: identification of phosphate transporters from higher plants. Plant Cell 9: 381-392

Lehrach H, Diamond D, Wozney JM \& Boedtker H (1977) RNA molecular weight determination by electrophoresis under denaturing conditions, a critical reexamination. Biochemistry 16: 4743-4751

Li R, Volenec JJ, Joern BC \& Cunningham SM (1998) Effect of phosphorus nutrition on carbohydrate and protein metabolism in alfalfa roots. J. Plant Nutri. 21: 459-474

Liu C, Muchhal US, Uthappa M, Kononowicz AK \& Raghothama KG (1998a) Tomato phosphate transporter genes are differentially regulated in plant tissues by phosphorus. Plant Physiol. 116: 91-99

Liu H, Trieu AT, Blaylock LA \& Harrison MJ (1998b) Cloning and characterization of two phosphate transporters from Medicago truncatula roots: regulation in response to phosphate and to colonization by arbuscular mycorrhizal (AM) fungi. Mol. Plant Microbe Interact. 11: $14-22$

Malboobi MA \& Lefebvre DD (1995) Isolation of cDNA clones of genes with altered gene expression levels in phosphate-starved Brassica nigra suspension cells. Plant Mol. Biol. 28: $850-870$

Muchhal US, Pardo JM \& Raghothama KG (1996) Phosphate transporters from the higher plant Arabidopsis thaliana. Proc. Natl. Acad. Sci. USA 93: 10519-10523

Muchhal US \& Raghothama KG (1999) Transcriptional regulation of plant phosphate transporters. Proc. Natl. Acad. Sci. USA 96: 5868-5872

Murashige T \& Skoog F (1962) A revised medium for rapid growth and bioassays with tobacco tissue cultures. Physiol. Plant. 15: 473-497 
Nelson DW \& Sommers LE (1973) Determination of total nitrogen in plant material. Agron. J. 65: 109-112

Paszkowski U, Kroken S, Roux C \& Briggs SP (2002) Rice phosphate transporters include an evolutionary divergent gene specifically activated in arbuscular mycorrhizal symbiosis. Proc. Natl. Acad. Sci. USA 99: 13324-13329

Peavey DG, Steup M \& Gibbs M (1977) Characterization of starch breakdown in the intact spinach chloroplast. Plant Physiol. 60: 305-308

Qui J \& Israel DW (1992) Diurnal starch accumulation and utilization in phosphorus-deficient soybean plants. Plant Physiol. 60: 316-323

Raghothama KG (1999) Phosphate acquisition. Annu. Rev. Plant Physiol. Plant Mol. Biol. 50: $665-693$

Rao IM, Fredeen AL \& Terry N (1990) Leaf phosphate status, photosynthesis, and carbon partitioning in sugarbeet. III. Diurnal changes in carbon partitioning and carbon export. Plant Physiol. 92: 29-36

Rebielle F, Bligny R \& Douce R (1982) Regulation of phosphate uptake by Acer pseudoplatanus cells. Arch. Biochem. Biophys. 219: 371-378.

Rosen H (1957) A modified ninhydrin colorimetric analysis for amino acids. Arch. Biochem. Biophys. 67: 10-15

Rufty WT Jr, Israel DW, Volk RJ, Qiu J \& Sa T (1993) Phosphate regulation of nitrate assimilation in soybean. J. Exp. Bot. 44: 879-891

SAS Institute (1999) The SAS system for Windows. Release 8.0. SAS Inst., Cary, NC

Sakano K (1995) Proton/phosphate stoichiometry in uptake of inorganic phosphate by cultured cells of Catharanthus roseus (L.) G. Don. Plant Physiol. 93: 479-483

Smith FW, Cybinski D \& Rae AL (1999) Regulation of expression of genes encoding phosphate transporters in barley roots. In: Gissel-Nielsen G \& Jensen A (eds) Plant Nutrition-Molecular Biology and Genetics. Kluwer Academic Publishers, Dordrecht, The Netherlands

Snedecor GW \& Cochran WG (1980) Statistical Methods. 7th edn. (p. 593). Iowa State University Press, Ames. Iowa, USA

Ukaji T \& Ashihara H (1986) Changes in levels of cellular constituents in suspension culture of Catharanthus roseus associated with inorganic phosphate depletion. Z. Naturforsch. 41c: 1045-1051. 


\section{Figure legend}

Figure 1. Dry weight accumulation of alfalfa cells as influenced by media P concentration. Cells were grown in B5g media supplemented with 0, 0.1, 0.5, 2.5, 5.0 and 10.0 mM P for 0, 3, 6 and 9 days. Data are means of three replicates. The least significant difference (LSD) is provided at 5\% level of probability (Experiment 1).

Figure 2. Changes in concentrations of sugar in the media, and cell sugar and starch in response to media $\mathrm{P}$ concentrations. Cells were grown in $\mathrm{B} 5 \mathrm{~g}$ media supplemented with $0,0.1,0.5$, 2.5, 5.0 and 10.0 mM P for 0, 3, 6 and 9 days. Data are means of three replicates. The least significant difference (LSD) is provided at 5\% level of probability (Experiment 1).

Figure 3. Cell amino acid (a) and buffer-soluble protein (b) concentrations of cultured alfalfa cells as influenced by P nutrition. Cells were grown in B5g media supplemented with 0, 0.1, 0.5, 2.5, 5.0 and 10.0 mM P for 0, 3, 6 and 9 days. Data are means of three replicates. The least significant difference (LSD) is provided at 5\% level of probability (Experiment 1).

Figure 4. Concentration of $\mathrm{P}$ in cell culture media (a), cultured cells (b), and total cell P uptake (c) as influenced by media P concentration for 0,3,6 and 9 days. Cells were grown in B5g media containing 0, 0.1, 0.5, 2.5, 5.0 and 10.0 mM P. Data are means of three replicates. The least significant difference (LSD) is provided at 5\% level of probability (Experiment 1).

Figure 5. Phosphorus uptake rate of cultured alfalfa cells grown for 9 days in media containing different $\mathrm{P}$ concentrations. Cells were grown in B5g media containing 0, 0.1, 0.5, 2.5, 5.0 and 10.0 mM P for 0, 3, 6 and 9 days. Uptake rates were calculated as the difference in cell P mass (Figure 4c) for the three intervals shown. Data are means of three replicates. The least significant difference (LSD) is provided at 5\% level of probability (Experiment 1).

Figure 6. Steady-state transcript levels for the alfalfa high-affinity P-transporter (MsPT1) as influenced by days in culture at various media P concentrations. Total RNA ( $20 \mu \mathrm{g} / \mathrm{lane})$ was 
493 isolated from suspension cells grown in B5g media containing $0,0.25,5.0$, and $10.0 \mathrm{mM}$

$494 \mathrm{KH}_{2} \mathrm{PO}_{4}$ for 0, 1, 3, 6 and 9 days (Experiment 2). 